\title{
Evidence-Based Practice: a survey regarding behavior, knowledge, skills, resources, opinions and perceived barriers of Brazilian physical therapists from São Paulo state
}

\author{
Tatiane M. Silva ${ }^{1}$, Lucíola C. M. Costa ${ }^{1}$, Leonardo O. P. Costa ${ }^{1,2}$
}

\begin{abstract}
Background: Evidence-Based Practice (EBP) has been widely used by health professionals. However, no study in Brazil has investigated the data regarding the knowledge and difficulties related to EBP from a representative sample of physical therapists. Objective: To identify behavior, knowledge, skills, resources, opinions and perceived barriers of Brazilian physical therapists from the state of São Paulo regarding EBP. Method: A customized questionnaire about behavior, knowledge, skills, resources, opinions and perceived barriers regarding EBP was sent by email to a sample of 490 physical therapists registered by the Registration Board of São Paulo, Brazil. Physical therapists who did not respond to the questionnaire were contacted by telephone and/or letter. The data were analyzed descriptively. Results: The final response rate was $64.4 \%$ (316/490). Because 60 physical therapists were no longer practicing, 256 answers were analyzed. The physical therapists reported that they routinely read scientific papers $(89.5 \%)$ as a resource for professional development, followed by continuing education courses ( $88.3 \%$ ) and books ( $86.3 \%$ ). Approximately $35 \%$ of the respondents reported a clear understanding of the implementation of research findings in their practice; approximately $37 \%$ reported no difficulties in critically appraising scientific papers; and $67.2 \%$ strongly agreed that EBP is important for their practice. The most commonly reported barriers were related to difficulties in obtaining full-text papers (80.1\%), using EBP may represent higher cost $(80.1 \%)$ and the language of publication of the papers $(70.3 \%)$. Conclusion: Physical therapists from São Paulo state believe that they have knowledge and skills to use EBP. Although they have favorable opinions regarding its implementation, they still encounter difficulties in implementing EBP successfully.
\end{abstract}

Keywords: Evidence-Based Practice; physical therapy; cross-sectional studies; Brazil.

\section{HOW TO CITE THIS ARTICLE}

Silva TM, Costa LCM, Costa LOP. Evidence-Based Practice: a survey regarding behavior, knowledge, skills, resources, opinions and perceived barriers of Brazilian physical therapists from São Paulo state. Braz J Phys Ther. 2015 July-Aug; 19(4):294-303. http:// dx.doi.org/10.1590/bjpt-rbf.2014.0102

\section{Introduction}

Evidence-Based Practice (EBP) is defined as "the conscientious, explicit, and judicious use of current best evidence in making decisions about the care of individual patients"1. However, patient's expectations, wishes and values, as well as the experience of the professional practitioner, also needs to be considered in the decision-making process ${ }^{2}$. EBP has been used as an important decision-making model $^{3}$ and contains five basic steps that should be followed to achieve success in applying its principles: 1) formulation of a clinical question; 2) conduct of an efficient database search to answer the clinical question; 3) critical assessment of the validity of the evidence; 4) application of the evidence findings in clinical practice; and 5) assessment of the clinical practice effects of the evidence application ${ }^{4}$.
Despite its well-defined principles, some obstacles may interfere in EBP, such as the limited availability of resources, the physical therapist's ability to competently apply an intervention considered to be the best based on the clinical evidence, socioeconomic and cultural factors ${ }^{2}$, or perhaps problems related to current health policies, the complexity of the physical therapy practice, access to full-text papers and continuing education programs ${ }^{5}$.

A recently published systematic review ${ }^{6}$ noted that the main barriers to EBP implementation by physical therapists were: lack of time, inability to comprehend statistical data, lack of employer support, lack of resources, lack of interest and lack of generalization of results of the studies to the patient ${ }^{6}$. The publication language, mostly English, might also be considered

\footnotetext{
${ }^{1}$ Programa de Mestrado e Doutorado em Fisioterapia, Universidade Cidade de São Paulo (UNICID), São Paulo, SP, Brasi 
a barrier that hinders the use of the pertinent studies due to the lack of understanding by readers who do not speak the language ${ }^{3}$. As an example regarding Brazilian physical therapists, less than $1 \%$ of all the applied clinical research indexed in PEDro database (Physiotherapy Evidence Database) is published in Portuguese ${ }^{7}$.

Previous studies have investigated different aspects of EBP in specific physical therapy populations ${ }^{6}$. One pilot study $^{8}(n=67)$ conducted in Brazil has addressed some of these characteristics by physical therapists in the state of Santa Catarina. Therefore, the examination of a representative sample that comprises most of the characteristics that affect EBP implementation by Brazilian physical therapists is needed.

The Health System in Brazil and the training of Brazilian physical therapists have unique characteristics compared with other countries (for example, while educational training in Brazil is performed on a University basis with a 4 to 5 years program, European countries such as the Netherlands and France provide training in a 2-3 years based on a technical program); therefore, a specific investigation is necessary. The present study aimed to identify the behavior, knowledge, skills, resources, opinions and perceived barriers of Brazilian physical therapists from the state of São Paulo (SP) regarding EBP.

\section{- Method}

\section{Study design}

This was a cross-sectional descriptive study conducted upon approval by the Ethics Committee of Universidade Cidade de São Paulo (UNICID), São Paulo, SP, Brazil, approved on March 20, 2013 (CAAE 13479213.6.0000.0064).

\section{Participants}

This study received institutional support from the Physical Therapy Registration Board of São Paulo (CREFITO-3). This Registration Board provided the data of 490 individuals chosen by random selection. All were physical therapists with valid certification by the Physical Therapy Registration Board of São Paulo, Brazil up to December 2012 and had valid email addresses. CREFITO-3 aided in sending the emails and, later in the research, provided the individual telephone numbers and addresses. All data were confidentially analyzed, with no interference from this Registration Board.

The study's sample size was based on an estimated response rate of $50 \%$. After several simulations using different samples sizes and maintaining the response rate at $50 \%$, it was decided that 450 participants would be needed to achieve high statistical precision. A sample of 450 participants and a $50 \%$ response rate, that would represent 225 expected respondents, would provide a sufficiently stable confidence interval that would not significantly change with doubling or quadrupling the sample. To prevent excessive drop out rates, the authors decided to recruit and collect the data from 490 individuals. These calculations were performed with the Confidence Interval Calculator of PEDro database?

\section{Questionnaire}

There was no existing appropriate questionnaire that addressed all the information the authors hoped to collect regarding the analyzed population, so a new questionnaire was developed. The questionnaire (Appendix 1S*) was developed from questions based on previous EBP studies ${ }^{10-15}$. This questionnaire consisted of questions divided into eight sections: 1) consent form; 2) current practice status; 3 ) demographic data; 4) behavior; 5) previous knowledge of EBP resources; 6) skills and available resources; 7) opinions about EBP; and 8) perceived barriers to EBP. The questionnaire was developed with multiple choice answers, and sections five, six and seven contained a 5-point Likert-type scale (where $1=$ =strongly disagree, $2=$ partially disagree, $3=$ neutral, $4=$ partially agree, and $5=$ strongly agree).

To guarantee better quality and understanding of the questionnaire, two pilot studies were performed prior to the final data collection. On the first pilot study, a printed version of the questionnaire was answered and analyzed by 31 physical therapy undergraduate students of UNICID to assess questions comprehension. On the second pilot study the questionnaire was sent via email to 50 physical therapy master's by coursework students of the same university to verify the quality of the submissions and the link-based response process.

\section{Procedures}

The data collection was performed with a formulated questionnaire at the SurveyMonkey website ${ }^{16}$, and was sent via email by CREFITO-3 to all 490 selected physical therapists. The email provided an invitation to participate in the study followed by the link to the questionnaire. All individuals who agreed to participate in the study did so as outlined in the consent terms.

\footnotetext{
* Supplementary materials are available online at http://www.scielo. $\mathrm{br} / \mathrm{scielo}$.php?script $=\mathrm{sci}$ issues\&pid $=1413-3555 \& \operatorname{lng}=\mathrm{en} \& \mathrm{nrm}=\mathrm{iso}$
} 
After the questionnaires were provided, the physical therapists had two weeks to answer the questions and to submit their responses. For the physical therapists who did not respond within this period, a new email was sent with the same response timeline. After two weeks, another notification was sent to the non-respondents. A fourth and final notification was sent two weeks later. Subsequently, attempts were made via telephone and then via letter to those with incorrect telephone numbers to maximize the response rate within ethical limits.

\section{Data analysis}

The data were descriptively analyzed using IBM SPSS software, version 19.0 for Windows, and were reported as absolute values, percentages and frequencies.

Based on our results, a secondary analysis was established due to possible differences in the responses according to time from graduation and English-language reading skills, which might be considered predictive of variability in the EBP characteristics evaluated. A gender-based analysis was also performed. These secondary analyses were performed using the chi-square test with the following characteristics: time from graduation, classified into four categories of less than 5 years, 5 to 9 years, 10 to 14 years and more than 14 years; English-language reading skills, classified as poor, moderate, good or excellent; and male or female gender. The level of significance was set at $\mathrm{p}=0.05$.

\section{Results}

The emails were sent by CREFITO-3 to all selected physical therapists. The cumulative response rate for the four email requests was 3.9\% (19/490). The response rate from data collected by telephone was $60.4 \%$ (296/490 with 22 refusals due to the lack of interest to participate). Letters were mailed to 81 physical therapists who had not responded to the emails and for whom the telephone data were invalid, with only one response. Thus, the final response rate was $64.4 \%$ (316/490), which included 256 practicing physical therapists and 60 who were non-practicing. The analyses were conducted with the 256 practicing physical therapists. Figure 1 shows all the phases of the study.

Table 1 describes the demographic characteristics of the participants. The majority of the respondents were female, had graduated less than 5 years prior to

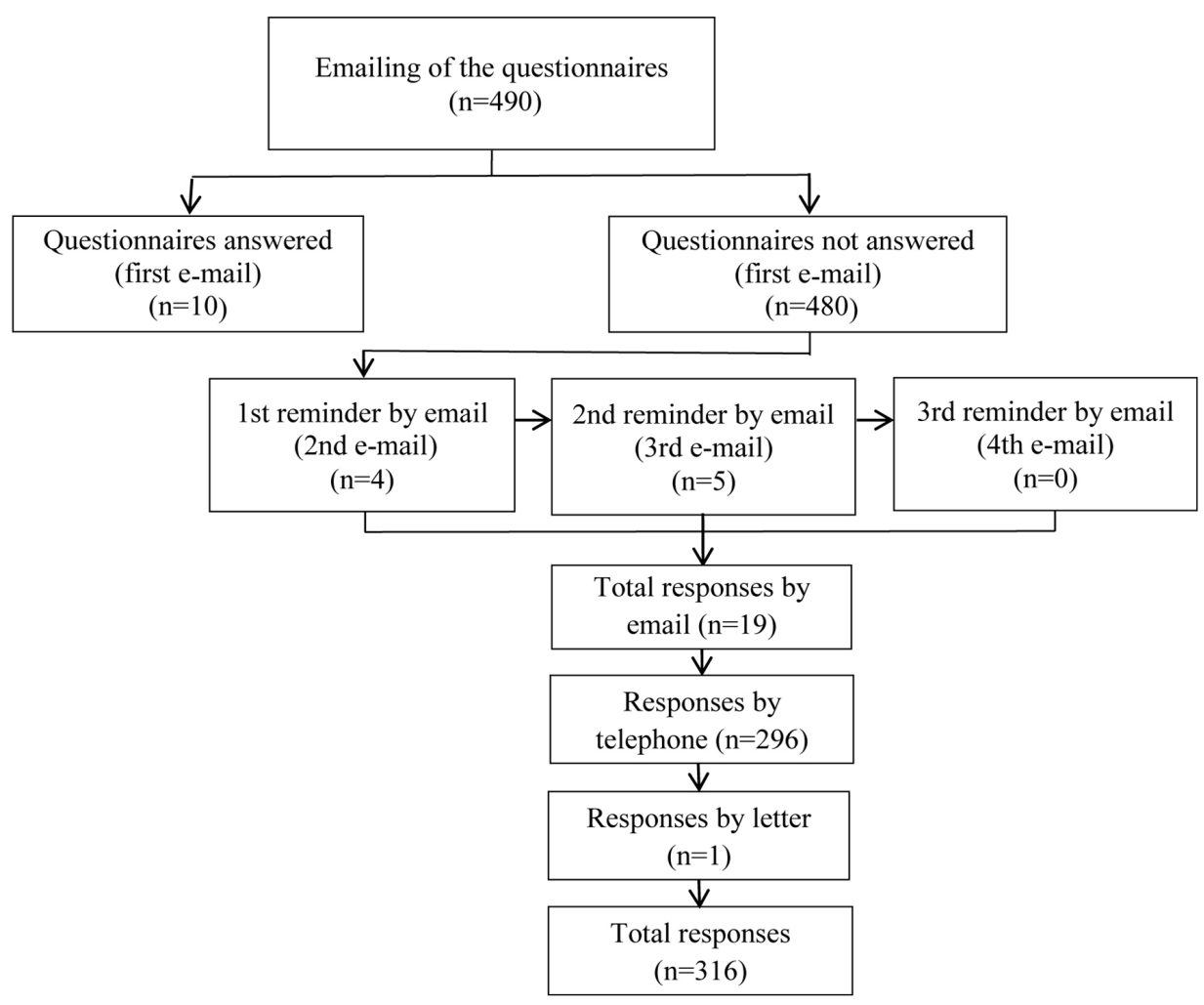

Figure 1. Flow diagram of the study. 
Table 1. Demographics of the respondents ( $\mathrm{n}=256$ ) of Evidence-Based Practice Questionnaire.

\begin{tabular}{|c|c|}
\hline Characteristics & n (\%) \\
\hline \multicolumn{2}{|l|}{ Gender } \\
\hline Female & $207(80.9)$ \\
\hline \multicolumn{2}{|l|}{ Time from graduation } \\
\hline Less than 5 years & 99 (38.6) \\
\hline $5-9$ years & $81(31.6)$ \\
\hline $10-14$ years & 45 (17.6) \\
\hline $15-19$ years & $13(5.1)$ \\
\hline $20-24$ years & $5(2.0)$ \\
\hline More than 24 years & $13(5.1)$ \\
\hline \multicolumn{2}{|l|}{ Highest level of education } \\
\hline Bachelor's degree & $78(30.5)$ \\
\hline Master's by coursework & $163(63.6)$ \\
\hline Master's by research & $14(5.5)$ \\
\hline Doctoral & $0(0)$ \\
\hline Postdoctoral & $1(0.4)$ \\
\hline \multicolumn{2}{|l|}{ Type of university/college } \\
\hline Private & $239(93.4)$ \\
\hline \multicolumn{2}{|l|}{ Current practice } \\
\hline Treating patients & $248(96.9)$ \\
\hline Teaching & $21(8.2)$ \\
\hline Research & $16(6.3)$ \\
\hline Other & $16(6.2)$ \\
\hline \multicolumn{2}{|l|}{ Area of interest } \\
\hline Musculoskeletal or orthopedics & $91(35.5)$ \\
\hline Cardiorespiratory & $53(20.7)$ \\
\hline Neurology & $35(13.7)$ \\
\hline Dermatology & $31(12.1)$ \\
\hline Acupuncture & $12(4.7)$ \\
\hline Public health & $10(3.9)$ \\
\hline Sports & $8(3.1)$ \\
\hline Workplace health & $6(2.3)$ \\
\hline Chiropractic and osteopathy & $5(2.0)$ \\
\hline Women's health & $4(1.6)$ \\
\hline Urogynecology & $1(0.4)$ \\
\hline Oncology & $0(0)$ \\
\hline \multicolumn{2}{|l|}{ Employment sector } \\
\hline Self-employed & $129(50.4)$ \\
\hline Private & $84(32.8)$ \\
\hline Public & $32(12.5)$ \\
\hline More than one & $11(4.3)$ \\
\hline \multicolumn{2}{|l|}{ Previous experience teaching } \\
\hline No & $201(78.5)$ \\
\hline \multicolumn{2}{|l|}{ Previous experience with research } \\
\hline Yes & $140(54.7)$ \\
\hline \multicolumn{2}{|l|}{ Self reported English-language skills } \\
\hline Poor & $74(28.9)$ \\
\hline Moderate & $117(45.7)$ \\
\hline Good & $56(21.9)$ \\
\hline Excellent & $9(3.5)$ \\
\hline
\end{tabular}

the study, held a master's by coursework, had attended private universities, were treating patients and were self-employed. Approximately $55 \%$ declared previous experience with research, which probably reflects the final treatises required for graduation and master's by coursework.

\section{Behavior in relation to $\mathrm{EBP}$}

Table 2 presents the respondents' characteristics regarding their behavior in relation to their use of research resources. The physical therapists reported using scientific papers $(89.5 \%)$ as a practice resource, followed by courses $(88.3 \%)$ and books $(86.3 \%)$. When asked about the databases they had already used, there was a clear preference for a Portuguese/Spanish databases, such as SciELO (86.7\%), compared to broader databases, such as PubMed $(71.9 \%)$ and Cochrane $(28.9 \%)$, or a physical therapy-specific database, such as PEDro (13.7\%).

\section{Knowledge, skills and resources, and opinions related to EBP}

Table 3 shows the percentage of physical therapists' responses by category to questions regarding their knowledge, skills, resources, and opinions related to EBP. The physical therapists reported having a clear understanding regarding the use of research findings in clinical practice ( $41.8 \%$ strongly agreed and $35.5 \%$ partially agreed) and about different types of study designs (40.2\% strongly agreed and $37.5 \%$ partially agreed) and having sufficient knowledge to apply EBP $(27.7 \%$ strongly agreed and $43.4 \%$ partially agreed); however, inconsistency was exhibited in the understanding of the core elements of EBP and about statistical data.

From the questions regarding skills and resources, it was noted that physical therapists reported no difficulties in critically assessing a scientific paper (29.3\% strongly agreed and $36.7 \%$ partially agreed) and that they reported routinely accessing databases (44.5\% strongly agreed and $29.3 \%$ partially agreed).

Regarding the questions about their opinions concerning EBP, the physical therapists reported being in favor of EBP since $67.2 \%$ strongly agreed and $25 \%$ partially agreed that EBP is important to clinical practice and $65.6 \%$ strongly agreed and $23.4 \%$ partially agreed that EBP improves patient care. Additionally, $31.3 \%$ strongly agreed and $41 \%$ partially agreed that EBP importantly contributes to their clinical decision-making; conversely, $16.8 \%$ strongly and $44.9 \%$ partially agreed that an expert's opinion is the most important factor in decision-making process. 
Table 2. Data regarding behavior of respondents and the use of Evidence-Based Practice.

\begin{tabular}{|c|c|}
\hline Characteristics & n (\%) \\
\hline \multicolumn{2}{|l|}{ Knowledge update methods } \\
\hline Scientific papers & $229(89.5)$ \\
\hline Courses & $226(88.3)$ \\
\hline Books & $221(86.3)$ \\
\hline Magazine-related articles & $191(74.6)$ \\
\hline Meeting, conferences, lectures & $174(68.0)$ \\
\hline Study groups & $50(19.5)$ \\
\hline \multicolumn{2}{|l|}{ Databases used } \\
\hline SciELO & $222(86.7)$ \\
\hline Lilacs & $205(80.1)$ \\
\hline Google Scholar & $204(79.7)$ \\
\hline PubMed & $184(71.9)$ \\
\hline Cochrane & $74(28.9)$ \\
\hline PEDro & $35(13.7)$ \\
\hline I have never used databases & $8(3.1)$ \\
\hline Other & $6(1.2)$ \\
\hline \multicolumn{2}{|l|}{ Databases more frequently used } \\
\hline SciELO & $122(47.7)$ \\
\hline PubMed & $68(26.6)$ \\
\hline Bireme & $50(19.5)$ \\
\hline Google Scholar & $48(18.8)$ \\
\hline Lilacs & $46(18.0)$ \\
\hline I do not use databases & $17(6.6)$ \\
\hline PEDro & $4(1.6)$ \\
\hline Cochrane & $2(0.8)$ \\
\hline Other & $1(0.4)$ \\
\hline \multicolumn{2}{|l|}{ Frequency of database use } \\
\hline Everyday & $5(2.0)$ \\
\hline 1 to 3 times a week & $62(24.2)$ \\
\hline 1 to 3 times a month & $70(27.3)$ \\
\hline Once every 2 months & $23(9.0)$ \\
\hline Very rarely & $38(14.8)$ \\
\hline I do not use databases & $58(22.7)$ \\
\hline \multicolumn{2}{|l|}{ Site of database use } \\
\hline Home & $205(80.1)$ \\
\hline Work & $64(25.0)$ \\
\hline University & $25(9.8)$ \\
\hline Other & $1(0.4)$ \\
\hline
\end{tabular}

\section{Barriers to EBP}

The most frequent barriers reported by physical therapists were mostly related to difficulty in obtaining full-text papers (80.1\%), using EBP might represent higher cost $(80.1 \%)$ and the language of publication of the papers $(70.3 \%)$. The less frequently cited barriers were lack of interest in research $(28.1 \%)$ and understanding the results of the studies $(24.6 \%)$. These data are shown in Figure 2.

The secondary analysis showed significant differences between the time-since-graduation categories, suggesting that physical therapists who had graduated within nine years had more knowledge and skills compared with those who had graduated more than nine years ago in response to the following questions: 'I had no experience with EBP in my graduate or postgraduate degree' $(p=0.001)$; 'The knowledge that I possessed during my graduate or postgraduate degree regarding EBP was sufficient' ( $p=0.004)$; 'I do not understand the core elements of EBP' ( $p=0.004)$; 'I am able to critically assess a scientific paper' $(\mathrm{p}=0.005)$; and 'I routinely access online databases' $(p=0.009)$. There were also significant differences in the English-language reading skills categories, suggesting that physical therapists with good or excellent skills had greater knowledge and skills than physical therapists with poor or moderate skills in response to the following questions: 'I do not understand the core elements of EBP' ( $p=0.009)$; 'I am not able to perform database searches' ( $p=0.003)$; and 'I am able to critically assess a scientific article' $(p=0.035)$. There were no significant differences between genders.

\section{Discussion}

The present study aimed to identify behavior, knowledge, opinions, skills and resources, and perceived barriers of physical therapists living in SP with regard to EBP. Despite favoring EBP implementation, the physical therapists living in São Paulo appear to value experts' opinions as well as using scientific papers, considering that $88.3 \%$ reported taking courses for professional development and $89.5 \%$ used scientific papers; moreover, $16.8 \%$ strongly and $44.9 \%$ partially agreed that an expert's opinion was the most important factor in decision-making, which contradicts one of the central pillars of EBP by which evidence should be provided by high-quality clinical research and not by experts' opinions ${ }^{17}$.

This finding may be related to the Brazilian education model, which is modeled on the teacher as the main actor in transferring knowledge to the students. This model may give the health professional the impression that knowledge rests on experts' opinions and not on EBP principles, disregarding the use of information contained in scientific papers as an adjunct in clinical decision-making.

Regarding the routine use of online databases, to which $44.5 \%$ strongly and $29.3 \%$ partially agreed, the most used was the SciELO database (47.7\%) and, to a lesser extent, PEDro (1.6\%) and Cochrane (0.8\%) databases. This preference might be justified by the languages adopted by SciELO database, i.e., Portuguese and Spanish, and the availability of full-text papers in that database. These can be important aspects for the physical therapists who considered the difficulty in 
Table 3. Knowledge, skills, resources, opinions of physical therapy practitioners regarding Evidence-Based Practice.

\begin{tabular}{|c|c|c|c|c|c|}
\hline & $\begin{array}{l}\text { Strongly } \\
\text { disagree }\end{array}$ & $\begin{array}{l}\text { Partially } \\
\text { disagree }\end{array}$ & Neutral & $\begin{array}{l}\text { Partially } \\
\text { agree }\end{array}$ & $\begin{array}{l}\text { Strongly } \\
\text { agree }\end{array}$ \\
\hline \multicolumn{6}{|l|}{ Knowledge } \\
\hline I know the meaning of the term Evidence-Based Practice (EBP). & 2.7 & 1.2 & 7.8 & 34.8 & 53.5 \\
\hline $\begin{array}{l}\text { I had no experience with EBP in my graduate or or postgraduate } \\
\text { degree. }\end{array}$ & 37.5 & 19.5 & 7.8 & 19.5 & 15.6 \\
\hline $\begin{array}{l}\text { The knowledge that I possessed during my graduate or } \\
\text { postgraduate degree regarding EBP was sufficient. }\end{array}$ & 25.4 & 30.1 & 10.9 & 23.4 & 10.2 \\
\hline I do not understand the core elements of EBP. & 26.6 & 22.3 & 21.5 & 22.3 & 7.4 \\
\hline $\begin{array}{l}\text { I have clear understanding regarding the use of research findings } \\
\text { in clinical practice. }\end{array}$ & 3.1 & 7.0 & 12.5 & 35.5 & 41.8 \\
\hline $\begin{array}{l}\text { I have an understanding regarding different types of studies (study } \\
\text { designs). }\end{array}$ & 3.1 & 5.9 & 13.3 & 37.5 & 40.2 \\
\hline I do not have understanding of statistical data. & 20.3 & 28.9 & 11.3 & 25.8 & 13.7 \\
\hline I believe I have sufficient knowledge to implement EBP. & 5.1 & 10.9 & 12.9 & 43.4 & 27.7 \\
\hline I am not interested in furthering my knowledge of EBP. & 68.8 & 14.5 & 7.8 & 6.6 & 2.3 \\
\hline \multicolumn{6}{|l|}{ Skills and resources } \\
\hline I am not able to perform database searches. & 34.8 & 28.9 & 16.0 & 15.2 & 5.1 \\
\hline I am able to critically assess a scientific paper. & 4.7 & 7.0 & 22.3 & 36.7 & 29.3 \\
\hline I routinely access online databases. & 4.7 & 7.8 & 13.7 & 29.3 & 44.5 \\
\hline I do not have incentive to implement EBP in my daily practice. & 27.0 & 11.7 & 22.7 & 13.7 & 25.0 \\
\hline $\begin{array}{l}\text { I have computer resources and Internet access at my workplace } \\
\text { that facilitate the implementation of EBP. }\end{array}$ & 15.2 & 6.3 & 17.6 & 16.8 & 44.1 \\
\hline I do not have discussions about EBP at my workplace. & 32.4 & 13.7 & 19.5 & 12.9 & 21.5 \\
\hline $\begin{array}{l}\text { I ask my patients about their preferences and I consider them in } \\
\text { my decision-making. }\end{array}$ & 3.9 & 4.7 & 7.8 & 33.2 & 49.6 \\
\hline $\begin{array}{l}\text { I inform my patients of their treatment options and involve them in } \\
\text { the decision-making. }\end{array}$ & 4.3 & 6.6 & 6.3 & 39.5 & 43.4 \\
\hline $\begin{array}{l}\text { I never try to deploy the best scientific evidence in my clinical } \\
\text { practice. }\end{array}$ & 54.3 & 21.5 & 14.1 & 7.4 & 2.7 \\
\hline \multicolumn{6}{|l|}{ Opinions } \\
\hline EBP is important to my clinical practice. & 1.2 & 0.4 & 6.3 & 25.0 & 67.2 \\
\hline $\begin{array}{l}\text { I do not believe that EBP improves patient care in physical } \\
\text { therapy. }\end{array}$ & 65.6 & 23.4 & 6.3 & 2.3 & 2.3 \\
\hline $\begin{array}{l}\text { Much of my decision-making regarding the treatment of my } \\
\text { patients incorporates EBP. }\end{array}$ & 3.5 & 8.6 & 15.6 & 41.0 & 31.3 \\
\hline $\begin{array}{l}\text { An expert's opinion in my field is the most important factor in my } \\
\text { decision-making process. }\end{array}$ & 5.5 & 17.2 & 15.6 & 44.9 & 16.8 \\
\hline $\begin{array}{l}\text { The use of the best current scientific evidence does not benefit the } \\
\text { quality of health services. }\end{array}$ & 48.8 & 31.3 & 10.9 & 7.0 & 2.0 \\
\hline
\end{tabular}

Variables expressed in percentages.

accessing full-text papers (80.1\%) and the language of publication of the scientific papers $(70.3 \%)$ as barriers.

However, these physical therapists disregarded the fact that reading papers only available in the full-text version in this condition might cause them to miss the most important papers, which is known as Full Text On the Net (FUTON) bias ${ }^{18,19}$. Additionally, the review of papers available exclusively in Portuguese or Spanish may not represent the best evidence available, which clearly shows a high level of language bias ${ }^{3,20}$. Finally, the frequency of database use among professionals was relatively low, and one-quarter of the respondents did not report using any database.
It is noteworthy that Brazil has broad access to databases through Bireme ${ }^{21}$, which grants free access to the Cochrane ${ }^{22}$ and SciELO ${ }^{23}$ databases. Capes e-journal web portal ${ }^{24}$ grants access only to public universities and a few private schools, along with other web portals that provide access to scientific journals. However, to effectively use these databases, proper training of the physical therapists and English-language reading skills are necessary.

The present study showed that physical therapists living in SP reported knowledge and specific skills for implementing EBP, such as the understanding of the application of research findings to clinical 


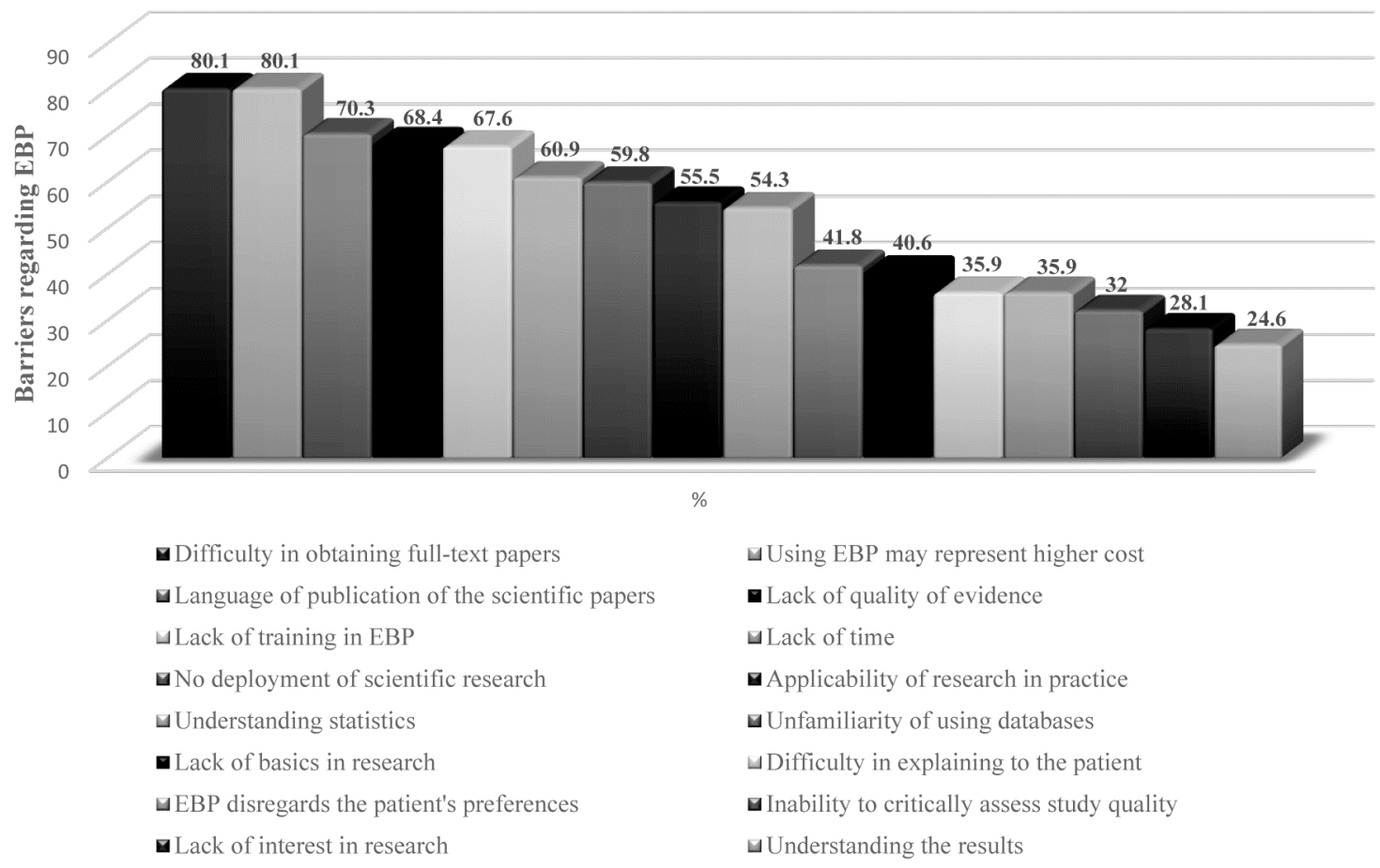

Figure 2. Barriers reported by respondents regarding Evidence-Based Practice (in percentages).

practice, the knowledge of different study designs and critically assess scientific paper. However, some of these professionals recognize that the EBP knowledge acquired during graduation was insufficient and that the lack of EBP training was an important barrier to its implementation (67.6\%).

The secondary analysis showed that physical therapists with less time since graduation as a physical therapist presented greater knowledge and skills compared with those with longer intervals since graduation as a physical therapist in some of the questions posed. Moreover, physical therapists with greater English-language reading skills also presented this characteristic when compared with those with poor or moderate reading skills. These data suggest that the training of physical therapists in the last decade might have shifted towards the use of research in clinical practice, with the introduction of specific courses on the subject. This also reinforced the importance of English language proficiency to improve the knowledge and specific skills of EBP.

In this study, the authors intended to obtain a random sampling among all registered physical therapy professionals in São Paulo state. Additionally, many efforts were made to maximize the response rate, as suggested in previous studies ${ }^{25,26}$, using email with three reminders as well as contact by telephone and letter. The authors achieved a satisfactory response rate $(64.2 \%)$ considering the response rates of similar studies, which have varied between $20 \%{ }^{27}$ and $81 \%{ }^{28}$. During the data collection, however, the authors found 81 invalid telephone numbers, and this might have negatively affected the final response rate. Surprisingly, the authors observed a very low response rate via email. It appears that this resource still has met with limited success in research in Brazil, unlike in other countries $^{28-30}$.

Although the Brazilian educational and health systems have particularities, the present data agree with existing studies reporting that physical therapists from other countries also believe they possess the knowledge to build a clinical question ${ }^{31,32}$, to search online databases ${ }^{28}$, to develop critical assessments ${ }^{30,32}$ and that they have common difficulties, such as the low frequency of database use $\mathrm{e}^{30,32,33}$ and the inability to comprehend statistical data ${ }^{29,34}$.

The pilot study ${ }^{8}$ conducted with a sample from the state of Santa Catarina demonstrated more optimistic perspectives of the physical therapists since $75 \%$ affirmed having knowledge of EBP, 50\% reported previous knowledge about its principles, and 59.7\% considered themselves confident in the critical analysis of scientific articles, as well as in searching for relevant scientific articles for their clinical practice. Physical therapists who participated in this study were also in favor of EBP implementation, considering that $48 \%$ 
agreed and $40 \%$ strongly agreed that EBP is necessary to physical therapy practice, and $68 \%$ reported using EBP in their daily practice ${ }^{8}$. Additionally, this study demonstrated important barriers such as lack of time, lack of generalization of results of the studies to patients, lack of information sources, and inability to apply the study's data to individual patients ${ }^{8}$.

The present study allowed the identification of specific barriers in this population, such as the difficulty in obtaining full-text papers and the language of publication of the papers. Efforts should be made to provide physical therapists easier access to scientific papers and to improve physical therapists' English comprehension because more than $90 \%$ of the clinical studies in physical therapy are published in English ${ }^{20}$.

The present study permitted a broad view of how EBP is viewed by physical therapists in SP, demonstrating that these professionals believed in having EBP knowledge and the necessary skills. They have also favorable opinions regarding its implementation. However, they exhibited uncertainty when asked about specific habits such as the use of databases, which points to the conclusion that despite EBP being increasingly discussed and its implementation encouraged, important gaps remain to be addressed.

These results imply the need for specific teaching strategies in EBP for this population that should focus on the main difficulties, such as the use of the major databases, which is the second necessary step for EBP application ${ }^{4}$. Moreover, by understanding EBP, the physical therapist is capable of offering a more effective approach, thus reducing the health costs.

One of the limitations of the present study was that no assessment of these professionals' actual knowledge about EBP was made using a specific tool to assess the effectiveness of their training, such as the Fresno test ${ }^{35}$. The Fresno test was recently adapted to Portuguese by Brazilian investigators ${ }^{36}$; however, this new version was not available when the present study was designed.

It warrants acknowledgement that perhaps the physical therapists living in São Paulo state are not representative of professionals from less economically developed regions of the country. However, it is unlikely that the results of this sampling would not also apply to other major centers, such as the capitals of the southern and southeastern states of Brazil. It would be important to conduct a study to confirm these results in a larger number of Brazilian states. Moreover, the possibility exists that in other states (for example, within the southeastern-southern axis) that do not present a significant number of EBP opinion leaders associated with masters or $\mathrm{PhD}$ programs, the EBP knowledge scores could be even less favorable.

The present study investigated behavior, knowledge, skills and resources, opinions and perceived barriers of Brazilian physical therapists living in the state of São Paulo, which allowed the identification of the primary difficulties they encountered in implementing EBP. Therefore, the authors suggest further studies on the effect of EBP-specific training skills that might resolve the weaknesses described in the present study.

\section{Conclusion}

Brazilian physical therapists living in São Paulo state believe that they have EBP knowledge and skills, and they present a favorable opinion regarding its implementation; however, difficulties remain in achieving its successful implementation. The primary barriers found in this study were related to obtaining the full-text articles (80.1\%), using EBP might represent higher cost $(80.1 \%)$ and language of publication of the scientific papers $(70.3 \%)$.

\section{Acknowledgements}

The authors would like to thank the Coordenação de Aperfeiçoamento de Pessoal de Nível Superior (CAPES) for their financial support and the Conselho Regional de Fisioterapia e Terapia Ocupacional da $3^{\text {a }}$ Região (CREFITO-3) for helping the authors in recruiting participants for this study.

\section{References}

1. Sackett DL, Rosenberg WM, Gray JA, Haynes RB, Richardson WS. Evidence based medicine: what it is and what it isn't. BMJ. 1996;312(7023):71-2. http://dx.doi. org/10.1136/bmj.312.7023.71. PMid:8555924.

2. Herbert R, Jamtvedt G, Mead J, Hagen KB, Chalmers I. Practical Evidence-Based physiotherapy. $2^{\text {nd }}$ ed. United Kingdom: Butterworth-Heinemann; 2011.

3. Maher CG, Sherrington C, Elkins M, Herbert RD, Moseley AM. Challenges for evidence-based physical therapy: accessing and interpreting high-quality evidence on therapy. Phys Ther. 2004;84(7):644-54. PMid:15225083.

4. Sackett DL, Straus SE, Richardson WS, Rosenberg W, Haynes RB. Evidence-based medicine: how to practice and teach EBM. $2^{\text {nd }}$ ed. New York: Churchill Livingston; 2000.

5. Haynes B, Haines A. Barriers and bridges to evidence based clinical practice. BMJ. 1998;317(7153):273-6. http:// dx.doi.org/10.1136/bmj.317.7153.273. PMid:9677226. 
6. Silva TM, Costa LCM, Garcia AN, Costa LOP. What do physical therapists think about Evidence-Based Practice? A systematic review. Man Ther. 2015;20(3):388-401. http:// dx.doi.org/10.1016/j.math.2014.10.009. PMid:25458142.

7. PEDro Physiotherapy Evidence Database. Health TGIfG [Internet]. [cited 2014 Dec 25]. Available from: http://www. pedro.org.au/english/downloads/.

8. Queiroz PS, Santos MJ. Facilidades e habilidades do fisioterapeuta na procura, interpretação e aplicação do conhecimento científico na prática clínica: um estudo piloto. Fisioter Mov. 2013;26(1):13-23. http://dx.doi. org/10.1590/S0103-51502013000100002.

9. PEDro Physiotherapy Evidence Database. Confidence interval calculator [Internet]. [cited 2014 Dec 25]. Available from: http://www.pedro.org.au/english/downloads/ confidence-interval-calculator/.

10. Madhavji A, Araujo EA, Kim KB, Buschang PH. Attitudes, awareness, and barriers toward EvidenceBased Practice in orthodontics. Am J Orthod Dentofacial Orthop. 2011;140(3):309-16.e2. http://dx.doi.org/10.1016/j. ajodo.2010.05.023. PMid:21889075.

11. Spallek H, Song M, Polk DE, Bekhuis T, Frantsve-Hawley J, Aravamudhan K. Barriers to implementing evidencebased clinical guidelines: a survey of early adopters. J Evid Based Dent Pract. 2010;10(4):195-206. http://dx.doi. org/10.1016/j.jebdp.2010.05.013. PMid:21093800.

12. Dahm P, Poolman RW, Bhandari M, Fesperman SF, Baum J, Kosiak B, et al. Perceptions and competence in evidencebased medicine: a survey of the American Urological Association Membership. J Urol. 2009;181(2):767-77. http://dx.doi.org/10.1016/j.juro.2008.10.031. PMid:19091333.

13. Caldwell K, Coleman K, Copp G, Bell L, Ghazi F. Preparing for professional practice: how well does professional training equip health and social care practitioners to engage in Evidence-Based Practice? Nurse Educ Today. 2007;27(6):518-28. http://dx.doi.org/10.1016/j. nedt.2006.08.014. PMid:17064821.

14. Metcalfe C, Lewin R, Wisher S, Perry S, Bannigan K, Moffett JK. Barriers to Implementing the Evidence Base in Four NHS Therapies. Physiotherapy. 2001;87(8):433-41. http:// dx.doi.org/10.1016/S0031-9406(05)65462-4.

15. Leach MJ, Gillham D. Are complementary medicine practitioners implementing evidence based practice? Complement Ther Med. 2011;19(3):128-36. http://dx.doi. org/10.1016/j.ctim.2011.04.002. PMid:21641517.

16. SurveyMonkey [Internet]. [cited 2014 Dec 25]. Available from: http://pt.surveymonkey.com/.

17. Dawes M, Summerskill W, Glasziou P, Cartabellotta A, Martin J, Hopayian K, et al. Sicily statement on EvidenceBased Practice. BMC Med Educ. 2005;5(1):1. http://dx.doi. org/10.1186/1472-6920-5-1. PMid:15634359.

18. Murali NS, Ghosh AK. Dissemination of science, FUTON bias and open access: implications for evidence-based medicine. Evid base Healthc Publ Health. 2005;9(6):374-5. http://dx.doi.org/10.1016/j.ehbc.2005.09.011.
19. Wentz R. Visibility of research: FUTON bias. Lancet. 2002;360(9341):1256. http://dx.doi.org/10.1016/S01406736(02)11264-5. PMid:12401287.

20. Shiwa SR, Moseley AM, Maher CG, Pena Costa LO. Language of publication has a small influence on the quality of reports of controlled trials of physiotherapy interventions. J Clin Epidemiol. 2013;66(1):78-84. http:// dx.doi.org/10.1016/j.jclinepi.2012.08.004. PMid:23177897.

21. Biblioteca Virtual em Saúde - BIREME. [Internet]. São Paulo: Centro Latino-Americano e do Caribe de Informação em Ciências da Saúde; 2014 [cited 2014 Dec 25]. Available from: http://www.bireme.br.

22. Portal de Evidências. [Internet]. São Paulo: Centro LatinoAmericano e do Caribe de Informação em Ciências da Saúde; 2014 [cited 2014 Dec 25]. Available from: http://evidences. bvsalud.org.

23. Scientific Electronic Library Online - SciELO. [Internet]. São Paulo: FAPESP, 2014. [cited 2014 Dec 25]. Available from: http://www.scielo.org.

24. Portal de Periódicos CAPES. [Internet]. Brasília: CAPES. [cited 2014 Dec 25]. Available from: http://www.periodicos. capes.gov.br.

25. Edwards PJ, Roberts I, Clarke MJ, Diguiseppi C, Wentz $\mathrm{R}$, Kwan I, et al. Methods to increase response to postal and electronic questionnaires. Cochrane Database Syst Rev. 2009;(3):MR000008. PMid:19588449.

26. VanGeest JB, Johnson TP, Welch VL. Methodologies for improving response rates in surveys of physicians: a systematic review. Eval Health Prof. 2007;30(4):303-21. http://dx.doi.org/10.1177/0163278707307899. PMid:17986667.

27. Scholten-Peeters GG, Beekman-Evers MS, van Boxel AC, van Hemert S, Paulis WD, van der Wouden JC, et al. Attitude, knowledge and behaviour towards evidencebased medicine of physical therapists, students, teachers and supervisors in the Netherlands: a survey. J Eval Clin Pract. 2013;19(4):598-606. http://dx.doi.org/10.1111/j.13652753.2011.01811.x. PMid:22128867.

28. Gorgon EJ, Barrozo HG, Mariano LG, Rivera EF. Research evidence uptake in a developing country: a survey of attitudes, education and self-efficacy, engagement, and barriers among physical therapists in the Philippines. J Eval Clin Pract. 2013;19(5):782-90. PMid:22583741.

29. Grimmer-Somers K, Lekkas P, Nyland L, Young A, Kumar S. Perspectives on research evidence and clinical practice: a survey of Australian physiotherapists. Physiother Res Int. 2007;12(3):147-61. http://dx.doi.org/10.1002/pri.363. PMid: 17624895 .

30. Jette DU, Bacon K, Batty C, Carlson M, Ferland A, Hemingway RD, et al. Evidence-Based Practice: beliefs, attitudes, knowledge, and behaviors of physical therapists. Phys Ther. 2003;83(9):786-805. PMid:12940766.

31. Iles R, Davidson M. Evidence based practice: a survey of physiotherapists' current practice. Physiother Res Int. 2006;11(2):93-103. http://dx.doi.org/10.1002/pri.328. PMid:16808090. 
32. Nilsagård YL, Lohse G. Evidence-based physiotherapy: a survey of knowledge, behaviour, attitudes and prerequisites. Adv Physiol Educ. 2010;12(4):179-86. http://dx.doi.org/1 $0.3109 / 14038196.2010 .503812$.

33. Salbach NM, Guilcher SJ, Jaglal SB, Davis DA. Factors influencing information seeking by physical therapists providing stroke management. Phys Ther. 2009;89(10):103950. http://dx.doi.org/10.2522/ptj.20090081. PMid:19661160.

34. Salbach NM, Jaglal SB, Korner-Bitensky N, Rappolt S, Davis D. Practitioner and organizational barriers to EvidenceBased Practice of physical therapists for people with stroke. Phys Ther. 2007;87(10):1284-303. http://dx.doi. org/10.2522/ptj.20070040. PMid:17684088.

35. Tilson JK. Validation of the modified Fresno test: assessing physical therapists' evidence based practice knowledge and skills. BMC Med Educ. 2010;10(1):38. http://dx.doi. org/10.1186/1472-6920-10-38. PMid:20500871.

36. Silva AM. Prática Baseada em Evidências: tradução, adaptação transcultural para o português brasileiro e teste de confiabilidade do instrumento FRESNO teste modificado para fisioterapeutas [thesis]. São Paulo: Universidade Cidade São Paulo; 2013.

\section{Correspondence}

\section{Tatiane Mota da Silva}

Universidade Cidade de São Paulo (UNICID)

Programa de Mestrado e Doutorado em Fisioterapia

Rua Monsenhor Francisco de Paula 264, Vila Aricanduva CEP 03504-000, São Paulo, SP, Brasil

e-mail: tati_911@yahoo.com.br 